\title{
FAMILY PLANNING VILLAGE PROGRAM IN RESPONSE TO THE USE OF LONG-TERM CONTRACEPTIVE METHOD
}

\author{
Program Kampung Keluarga Berencana dalam Merespon Penggunaan \\ Kontrasepsi Jangka Panjang

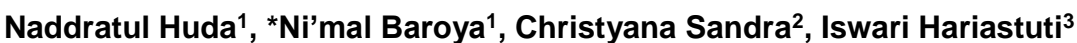 \\ 'Division of Biostatistics and Population, Faculty of Public Health, University of Jember, Indonesia \\ ${ }^{2}$ Division of Health Policy and Administration, Faculty of Public Health, University of Jember, Indonesia \\ ${ }^{3}$ National Board of Family Planning and Population, East Java, Indonesia \\ ${ }^{*}$ Correspondence: nbaroya@unej.ac.id
}

\begin{abstract}
Background: Contraceptive use in Indonesia was still dominated by short-term contraception. Thus, Family Planning Village is created for promoting a Long-Term Contraception Method (LTCM).

Aim: This study analyzed the implementation of the Family Planning Village Program for LTCM use in Dukuhsia Rambipuji, Jember.

Method: This study was descriptive with a mixed-method approach. All of LTCM users in Dukuhsia amounting to 24 participated in the quantitative study. While there were five informants who were selected purposively in the qualitative research, including a Family Planning field worker, Coordinator of Women Empowerment, Child Protection and Family Planning Office, a midwife, Advocate Assistant for Village Family Planning, and a cadre under the Advocate Assistant for Village Family Planning. Qualitative data were obtained through in-depth interviews while quantitative data through structured interviews using questioner. Data were then analyzed using the Miles and Huberman Models and statistical-descriptive analysis.

Results: Most aspects of the input factor were not in accordance with the technical guidelines of Family Planning Village. Whereas the implementation method complies with the guidelines. Most aspects of the process factor were relevant to the guidelines, but there were still many obstacles in the implementation. Good participation in the family planning village program is only $37.5 \%$. Since the program launch, the prevalence of long-term contraceptive use increase from $6.07 \%$ to $6.21 \%$. However, it does not significantly increase the use of LTCM because the prevalence was much smaller than the prevalence of LTCM at the village level.

Conclusion: The implementation of the Family Planning Village in Dukuhsia could increase LTCM users. However, it could not increase the ideal proportion of LTCM users. Therefore, it is necessary to improve input and process of the Family Planning Village through the Contraceptive Technology Update (CTU) training for midwives and conduct a training of LTCM use for cadres to enhance their communicative skill in campaigning the use of LCTM.
\end{abstract}

Keywords: users, contraception, family planning village, implementation.

\section{ABSTRAK}

Latar Belakang: Penggunaan metode kontrasepsi di Indonesia didominasi oleh kontrasepsi jangka pendek. Oleh karena itu, pemerintah merintis program kampung KB sebagai salah satu upaya promosi peningkatan penggunakan Metode Kontrasepsi Jangka Panjang (MKJP).

Tujuan: Penelitian ini bertujuan untuk menganalisis implementasi Program Kampung KB terhadap penggunaan Metode Kontrasepsi Jangka Panjang (MKJP) di Dukuhsia Rambipuji Jember.

Metode: Jenis penelitian ini adalah deskriptif dengan metode campuran (mixed method). Responden untuk penelitian kuantitatif adalah seluruh pengguna MKJP di Dukuhsia yang berjumlah 24. Adapun informan untuk penelitian kualitatif sebanyak 5 orang yang ditentukan secara purposive, yaitu Petugas Lapangan Keluarga Berencana (PLKB), Koordinator Dinas Pemberdayaan Perempuan, Perlindugan Anak dan Keluarga Berencana (DP3AKB), bidan, Pembantu Pembina Keluarga Berencana Desa (PPKBD), dan kader Sub PPKBD. Data kualitatif diperoleh melalui wawancara sedangkan data kuantitatif diperoleh melalui wawancara terstruktur menggunakan kuesioner. Data kemudian dianalisis menggunakan Model Miles dan Huberman dan analisis statistik-deskriptif.

Hasil: Sebagian besar aspek input belum sesuai dengan pedoman teknis Kampung KB, hanya aspek metode yang sudah sesuai dengan pedoman. Sebagian besar aspek proses sesuai dengan pedoman tetapi masih ada banyak hambatan implementasi. Partisipasi yang baik dalam program Kampung KB hanya 37,5\%. Sejak program Kampung KB diluncurkan, prevalensi MKJP meningkat dari 6,07\% menjadi 6,21\%, tetapi belum meningkat secara 
ignifikan karena prevalensinya sangat kecil dibandingkan dengan prevalensi MKJP di tingkat desa.

Kesimpulan: Implementasi program kampung KB di Dukuhsia dapat meningkatkan jumlah akseptor MKJP, namun kenaikan tersebut belum mampu meningkatkan proporsi MKJP kampung KB secara signifikan. Dengan demikian perlu perbaikan pada aspek input dan proses pengelolaan Kampung KB melalui pelatihan Contraceptive Technology Update (CTU) untuk bidan dan memberikan pelatihan bagi kader untuk meningkatkan kemampuan berkomunikasi dalam mengkampanyekan penggunaan MKJP.

Kata kunci: pengguna, kontrasepsi, kampung keluarga kerencana, implementasi.

\section{INTRODUCTION}

Indonesia still faces several issues related to family planning and reproductive health, which can weaken the implementation of the Family Planning and Family Development Population program (National Board of Population and Family Planning, 2015). Family Planning Program, according to Law No. 52 of 2009, is defined as an effort to regulate childbirth, pregnancy span, and ideal age for childbirth through promotion, protection, and assistance in accordance with the reproductive rights for excellent families. The World Health Statistics reported data from 2005-2012 that the use of contraception in Indonesia has exceeded the average compared to other ASEAN countries but is still lower than in Vietnam, Cambodia, and Thailand. The data of Family Planning Worldwide in 2008 showed the number of fertile aged women in Indonesia is the highest among other ASEAN countries around 65 million fertile women. In other words, it still increases the number of Contraceptive Prevalence Rate (CPR) (Indonesian Ministry of Health, 2013).

The contraceptive methods, according to the period of use, are divided into two ways; the long-term contraceptive method, and the short-term contraceptive method. The most effective way for reducing birth rates is a long-term contraceptive method. Long-term contraception can be used for an extended period time (more than two years) and are practical and efficient for the birth spacing of more than three years or birth control for couples who do not want to have more children. Types of long-term contraception are male and female regular contraception (tubectomy and vasectomy), Implant and Intra-Uterine Device (IUD) (National Board of Population and Family Planning, 2016).

Based on data from the East Java Provincial National Population and Family Planning Board in 2017, it was found that the coverage of active family planning participants in East Java Province reached 74.39\% (East Java Provincial National Board of Population and Family Planning, 2017). This coverage rate increased compared to that in 2016, which reached $68.79 \%$. Whereas, the coverage of new family planning participants decreased in 2015 from $10.6 \%$ to $10.4 \%$ in 2016 (East Java Provincial Health Office, 2017). Family planning participation in Indonesia is still dominated by the use of short-term contraception, such as the injection method (58.4\%) and pill (17.3\%). According to the Regency/City of East Java Province in 2015, the long-term contraception in Jember District was ranked as the 8th lowest percentage. However, the proportion of new family planning participants that use long-term contraception in Jember District was ranked as the tenth lowest (East Java Provincial Health Office, 2015). Based on these data, it is known that the use of short-term contraception is higher than long-term contraception. However, Couple Years of Protection (CYP) during 3-5 years give a small opportunity for discontinuing the use of contraception (0$20 \%$ compared to short-term contraception method (20-40\%). CYP is 
estimated protection from pregnancy given contraception for one year (Indonesian Ministry of Health, 2013).

Short-term contraceptive methods in Jember District are more dominated, while the use of long-term contraceptives methods was deficient. The number of vasectomies used was $1.1 \%$, and the use of tubectomy was $1.5 \%$ (Jember District Health Office, 2016). The long-term contraceptive method is not preferred much because the short-term contraceptives are more affordable and easy to use (Jember District Health Office, 2014).

The Population in Indonesia is very complex, and society still opts the shortterm contraceptives, which in turn need special treatment. Because of that, the government initiated the Family Planning Village Program, which aims to achieve the development priority (Nawacita) from 2015 to 2019. The Family Planning Village strengthens the Family Planning Population and Family Empowerment Program, which is managed and organized from, by, and for the community. It facilitates the city with family planning services. The Family Planning Services involve Community Villages, Orchards, or equivalent regional units, which integrate the population programs, family planning, family empowerment, and other related empowerments (National Board of Population and Family Planning, 2015). Family planning programs in Jember District were firstly implemented in Dukuhsia, Rambigundam Village, in March 2016 because it had a small number of long-term contraception. However, after the program was implemented, the increase in the number of long-term contraceptive users did not meet the target. Based on the issues, this study pointed out how the Family Planning Village Program was implemented to increase the use of long-term contraceptive methods in Dukuhsia, Jember, in 2017.

\section{METHOD}

This research was descriptive using a mixed-method approach with a sequential exploratory design, which explored the data qualitatively and quantitatively (Sutopo, 2014). This study was conducted from June until August 2018. The first stage of this study used a qualitative approach. There five informants were selected purposively, such as a Family Planning field worker, Coordinator of Women Empowerment, Child Protection and Family Planning Office, a midwife, Advocate Assistant for Village Family Planning, and a cadre under the Advocate Assistant for Village Family Planning. The qualitative data were obtained through indepth interviews and supported by the documentation of the Family Planning Village Program in Dukuhsia. The secondary data at the qualitative stage included documents related to inputs (man, money, materials, methods, facilities and infrastructure and targets) and process (duration of meetings, miniworkshops, community village meeting, and documentation). This study analyzed qualitative data using the Miles and Huberman Models. This model analyzed qualitative data interactively, continuously until the data-saturated with the stages of data reduction, data display, and concluding.

While at the second phase this study used a quantitative approach which involved all of LTCM users as many as 24 repsondents in Dukuhsia. Variables examined at this stage were knowledge of LTCM, participation of family planning, family planning service, distance, and travel time to access family planning services. Knowledge variable was divided into three categories, i.e., good if the respondents answered $>8$ questions 
correctly, moderate if the respondents had 6-8 correct answers, and less if they got $\leq$ 5 correct answers. Participation in the family planning village program was categorized into three, i.e., good if the respondents answered "yes" to >8 statements, moderate if they answered "yes" to 6-8 statements, and less if they answered "yes" to $\leq 5$ statements.

This study also measured access variables consisting of distance and travel time to the LTCM services. Distance is a physical length that the respondentd have travelled from home to the LTCM services. It was classified into 3 criteria, which were $\leq 3 \mathrm{~km}, 3-15 \mathrm{~km}$ and $\geq 15 \mathrm{~km}$. Travel time is the length of time spent to travel from home to the LTCM services in minutes as the unit of measurement. Travel time was grouped into 3 categories, such as $\leq 10$ minutes, $10-30$ minutes and $\geq 30$ minutes.

The quantitative data were collected through structured interviews with question guidelines and documentation of the target reports of long-term contraception program and users in Dukuhsia. The quantitative data were then analyzed by using univariate analysis and explained descriptively.

\section{RESULTS AND DISCUSSION}

\section{The Input of Family Planning Village Program}

Input is data put into a system or extended into action to achieve an output or result. Information refers to resources needed for implementing an activity or intervention. Human resources, materials, and financial resources are input indicators. Human resources were related to respondents' and program implementers' characteristics.

Respondents' characteristics consist of sex, age, education level, and income. It was found that the respondents were all women (100\%) since there were no males who used a vasectomy method. A husband or male respondent is an indicator of the success of the Family Planning Program. The stigma about female participants in the family planning program commonly makes the majority of males unwilling to participate. Moreover, males acknowledge that the Family Planning Program was carried out by mostly female workers. Such a social problem that perceives a wrong concept of contraception causes limited access for husbands to understand it (Muhatiah, 2012).

The respondents are mostly at the age of $<40$ years and $40-50$ years. It was noticed that generation tends to affect the choice of contraceptives. Respondents aged 30 tend to choose long-term contraceptives compared to respondents where less than 20 years old (Lontaan, Kusmiyati, and Dompas, 2014). The older the age of the respondent, the more likely they use long-term contraception (Dewi, 2017).

Most of the respondents have graduated from junior high school/equivalent, and some have graduated from high school/equivalent. Respondents with higher education have a broad view of something, and it is easier to accept ideas or inputs (Rosmadewi, 2015). Education can affect one's understanding of various things and become a foundation in preparing, forming, fostering, and developing resources (Yanti, Hasballah, and Mulyadi, 2016).

The dominant occupations of the respondents are entrepreneurs. Others have no work and are farmers, laborers, and civil servants. They mostly have income below the regional minimum wages. Respondents who are in middle and lower economic status prioritize primary needs other than contraceptives. Therefore, they prefer to use short-term contraception, such as pills and injections, 
which are cheaper (Murniati, Astuti, and Juliantari, 2016).

In organizing the Family Planning Village, females at the age of 30-50 years take more control. Females at this age are considered capable of self-development and community empowerment. In general, they have the ability to perform the program well (Devi, Fatchiya, and Susanto, 2016).

Characteristics of program implementers consist of gender, age, education level and years or working. The program implementer is an organizational component that carries out tasks that have been determined from above. The executor is the person who is assigned to carry out the management as well implement programs to achieve organizational program goals. The role of program implementers is very important in the success of the program. Program implementers in this study were a Family Planning field worker, Coordinator of Women Empowerment, Child Protection and Family Planning Office, a midwife, Advocate Assistant for Village Family Planning, and a cadre under the Advocate Assistant for Village Family Planning.

Most of the implementers are female. The composition of the age of the implementing family planning village is 30 50 years. This age group is still productive for self-development and the development of family planning programs. In general, implementers in this age group have the ability to move that is still quite good. This is a potential in family planning counselling. Females who organize the Family Planning Program have various educational levels from school to college level. High knowledge, positive attitudes, and top skills will make them more adaptive to change, able to overcome problems well, plan and evaluate work appropriately (Devi, Fatchiya, and Susanto, 2016).
The Family Planning Program in Dukuhsia Village began on March 22, 2016, so some of the implementers had a two-year working period. The working period is an indicator of productivity because people have more experience and skills in completing tasks (Yanti and Hasballah, 2016).

In terms of funding, the Family Planning Village Program was sponsored by the State Budget, Provincial National Population, and Family Planning Board, Local Government Work Unit, Regional Government Budget, Village Budget, or other related sectors. However, the Family Planning Program in Dukuhsia did not receive any funding.

"The first program was implemented in Dukuhsia and Tanggul. Tanggul becomes the comparison, but Dukuhsia is the main implementer. Someone said the Family Program in Dukuhsia was funded by the Government, but until now they got nothing. Instead, the Family Planning Program in Rambipuji was divided into two funding streams. The new Family Planning Program is funded using the assistance fund for operational cost (BOK), but the old program is always selffunded..." (Family Planning Field Worker)

One indicator of success in the Family Planning Village Program is the integrated activities among cross-sectoral partners. The budget support for the program implementation comes from Regional Government Budget I, Regional Government Budget II, Village Budget as well as other non-binding funds (National Board of Family Planning and Population, 2016). Practically, the Family Planning 
Village Program in Dukuhsia was never offered funding. Funding for family planning activities in the village only comes from external partners. As a result, the cadres did not get any commission for implementing the Family Planning Village Program. Therefore, the Coordinator of Jember Women Empowerment and Child Protection gave commission for cadres in every activity of Family Planning Program. Cadres helped Advocate Assistants for Village Family Planning and usually got reward of IDR 150,000 for attending every activity.

"There are Advocate Assistant
for Village Family Planning
and the cadre of Advocate
Assistant for Village Family
Planning. So far they have
never received honorarium
unless there are activities. The
Advocate Assistant for Village
Family Planning will get
150,000 Rupiah even bigger,
such as three or four million in
a year. However, they just
took 50,000 Rupiah, and the
rest was given to the cadred
who helped them. If the
activity is conducted in the
village hall or anywhere, the
cadres will get 10,000-15,000
Rupiah for transportation
fare." (Coordinator of Women
Empowerment,
Protection and Family
Planning Office)

In addition to commission, the Family Planning Village Program should be supported by decent facilities and infrastructure especially contraceptives, medical devices for the installation of contraception, counselling, media for Family Planning Population and Family Empowerment and service cars. Based on the interviews, it was said that facilities and infrastructure for the Family Planning Village in Dukuhsia are still not fully complete. However, the Village provides free long-term contraceptives. Improving facilities for the program will create a conducive working atmosphere so that work can be completed effectively and efficiently (Afniyanti, 2016).

To increase the users of long-term contraceptives, the program provides free for contraceptives services, counselling, and socialization. Free for contraceptive services is held by cross sectors such as Indonesian Midwives Association, polices, and soldiers. The socialization of Family Planning Program was conducted in integrated service post, and Family Welfare Program. If socialization or counselling is in a group, it will be more about interpersonal communication (Afniyanti, 2016).

The target society expected to participate in the Family Planning Program are couples at childbearing age. Fertile couples are directed to become active cadres so that they are knowledgeable about the issues of population. It is expected that they can contribute to increase the number of long-term contraceptive users as the Government has set.

\section{The Process of Family Planning Village Program}

The process of the Family Planning Village Program begins with planning stage. At this stage, the implementers plan activities during a year ahead. Nevertheless, there are some incidental activities that arise outside the initial planning. The planning activities are quarterly held usually in pre-schools, village head's house, and program treasurer's house. Planning has a positive and significant relationship with the success of a program because it determines a series of actions to achieve optimal outcomes (Kurnia, 2013). 
"We participated in making a work plan, joined together, including with the supervisor, with the head of management in all activity group we invited when making plans. We can usually do it every 3 months or 4 months there is an evaluation...." (The Midwife)

Organizing is an activity to handle human resources into labor, work relations, delegation of authority, integration and coordination in the organizational structure. Coordination among administrators in the Family Planning Village Program was quarterly conducted. Moreover, coordination is also done informally through social media and cell phones. Good coordination in work will also improve the performance of the implementers (Afniyanti, 2016).

"That is cross-sectoral coordination. We usually meet in the maternal and child health services or at the subdistrict office where we do fingerprint. We set their fingerprint attendance here to gather them in a while for chatting with them. It is just our strategy. The soldiers collect data here and talk about their programs". (Family Planning Field Worker)

In turn, after the Family Planning Village Program had been implemented, the number of long-term contraceptive users increased from $6.07 \%$ to $6.21 \%$. The increase can be achieved presumably because of the Contraceptive Technology Update (CTU) training for Dukuhsia midwives and training for cadres to improve their ability of socialization to the community. Training has a significant influence on performance (Landa, 2018). The skills of cadres in communication, data processing and coordination greatly affect performance. Training can equip cadres to improve the quality of Advocacy Assistant for Village Family Planning performance (Muslikh and Nugraha, 2014). The availability of contraceptives in Dukuhsia Village thus increases the access to obtain family planning services. The users who get complete facilities and infrastructures for family planning services tend to use the long-term contraceptives (Fienalia, 2012). There is an organizational structure that provides a job description for each implementer so that the program activities can run systematically. Along the streets, the Dukuhsia Village give names with types of contraceptives so as to improve people's memory about it.

The Family Planning Village Program has been established since 2016, and it still requires an accountability. Accountability is carried out by evaluating each Family Planning Village Program at the end of the year and quarterly reporting inventory activities. In addition, it also was accompanied by monitoring and supervision from Family Planning Outreach Workers of Rambipuji, Rambipuji Women Empowerment and Child Protection and Representatives of East Java Provincial the National Board of Population and Family Planning.

"Supervision is done from top to bottom gradually. Some are coordinated from top to the village who has the Family Planning Program. Sometimes it comes from here to the village. We sometimes cooperate with other institutions, talk about the progress. The Jember Women Empowerment and Child Protection always cooperate 
with Primary Health Care. The Women Empowerment, Child Protection and Family Planning conducted supervision for 3 up to 4 times..." (Advocate Assistant for Village Family Planning)

Monitoring and supervision can have a positive effect on the performance of the program implementers. Supervision tends to be related with family planning services according to the Standard Operating Procedure. It indicates that the implementers who receive supervision tend to provide family planning services based on the Standard Operating Procedure. Guidance can increase the motivation of cadres and other implementers in improving the quality of services in the Family Planning Villages (Rahayu, 2016).

The indicator of success is Rambipuji. Thus, the Family Planning in Dukuhsia Village will be considered successful if the increase in long-term contraceptives in Dukuhsia is higher than in Rambipuji.

"The indicator of success is the Village whether there is an increase in the number of long-term contraceptive users. If the Village has more, it means that the program is successful..." (The cadre under the Advocate Assistant for Village Family Planning)

Based on the interview, it can be seen that the Family Planning Program in Dukuhsia has only been run for two years, but there are many benefits and perceived changes. There is great hope to continuously support further programs to help the community progressive.

\section{Outputs of Family Planning Village Program}

Table 1 shows that more than half of respondents have relatively sufficient knowledge (>50\%). Total of $16.17 \%$ had less knowledge about long-term contraceptive methods and as many as $25 \%$ of respondents had good knowledge of long-term contraceptive methods. Knowledge about family planning, especially long-term contraception has an important role in the success of Family Planning Program. Lack of knowledge of family planning causes husbands not to allow their wives to use long-term contraceptives, so wives tend to choose short-term contraceptives instead (Murniati et al., 2016). One of important factor in the long-term contraception is client's knowledge (Tibaijuka et al., 2017), so good knowledge will be useful for improving better utilization of long-term contraceptives (Getahun et al., 2018). Because of that, community's knowledge of the Family Planning Program in Dukuhsia still needs to be improved.

Table 1. Knowledge of Respondents about Long-Term Contraceptives.

\begin{tabular}{lrr}
\hline Knowledge & $\mathbf{n}$ & $\%$ \\
\hline Less & 4 & 16.2 \\
Moderate & 14 & 58.3 \\
Good & 6 & 25.0 \\
\hline Total & 24 & 100 \\
\hline
\end{tabular}

Table 2. Respondent Utilization to LongTerm Contraceptive Method Services.

\begin{tabular}{lrl}
\hline $\begin{array}{l}\text { Places of } \\
\text { Service }\end{array}$ & $\mathbf{n}$ & $\%$ \\
\hline Hospitals & 8 & 33.3 \\
Primary & 16 & 66.7 \\
Healthcare & & \\
Centers & & \\
\hline Total & 24 & 100 \\
\hline
\end{tabular}


Primary healthcare center in this case include Rambipuji Primary Healthcare Center, auxiliary primary healthcare center and village maternity clinic (polindes). Family planning services provided by the primary healthcare centers involve the installation of implant and IUD. Some other respondents received tubectomy services at hospitals, such as Dr. Soebandi Hospital, Balung Hospital, Jember Clinic Hospital and Bina Sehat Hospital. There were no respondents who received family planning services at clinics, midwives or other practices. Family planning services that are close to home or near to workplace are more preferred by the contraceptive users (Muhatiah, 2012). In Dukuhsia Village, the closest health facilities are primary healthcare centers, auxiliary primary healthcare centers, and village maternity clinic. Therefore, the community are more likely to use contraceptives that can be accessed here.

Table 3. Distance and Travel Time for Respondents to Health Facilities.

\begin{tabular}{lcr}
\hline \multicolumn{1}{c}{ Distance } & $\mathbf{n}$ & $\%$ \\
\hline$\leq 3 \mathrm{~km}$ & 16 & 66.7 \\
$3-15 \mathrm{~km}$ & 1 & 4.2 \\
$\geq 15 \mathrm{~km}$ & 7 & 29.2 \\
\hline Total & 24 & 100 \\
\hline Travel Time & & \\
\hline$\leq 10$ minutes & 16 & 66.7 \\
10 & 1 & 4.2 \\
minutes & & \\
$\geq 30$ minutes & 7 & 29.2 \\
\hline Total & 24 & 100 \\
\hline
\end{tabular}

In terms of distance, the majority of respondents travel $\leq 3 \mathrm{~km}$ to primary healthcare centers. Another travels 3 - 15 $\mathrm{km}$ to the Jember Clinic Hospital, Bina Sehat Hospital, and Dr. Soebandi Hospital, and others travel $\geq 15 \mathrm{~km}$ to Balung Hospital. Respondents whose house is near to family planning services have 4.3 times greater chance to use longterm contraceptives compared to those far from the services (Oyugi et al., 2017).

Furthermore, most of the respondents spend $\leq 10$ minutes to primary healthcare centers. Some take $\geq$ 10 minutes to the Jember Clinic Hospital, Bina Sehat Hospital, and Dr. Soebandi Hospital. The other one respondent \pm 30 ie travel time to RSD Balung.

Result and Discussion section contains a description of the main results of the research. It is suggested to the writer to convey the main and important result, but not impressed to read the table containing the research result. respondent travels in \pm 30 minutes to Balung Hospital. Easy access with a travel time of less than thirty minutes can attract couples to visit the family planning services. It is relevant with the argument of Tesfaey Haile and Anjullo that distance to health services affects the increase in family planning participants (Tesfaye Haile and Anjullo, 2018). As seen in Dukuhsia Village, the respondents prefer health facilities that can be reached out in \pm 5 minutes by motorbikes. It is supported by Muhatiah that health facilities attract more people if it has accessible transportations (Muhatiah, 2012).

The results also showed that all respondents were not required to make payments for family planning services. Respondents who receive IUD and implants treatment only bear transportation cost. Whereas for tubectomy and vasectomy respondents, there is no charge at all either for the treatment cost or transportation cost. Free services tend to encourage community to use contraceptives (Kartika, Budihastuti and Pamungkasari, 2018). Thus, freecharge family planning services can increase participation.

From Table 4, it draws a conclusion that there are respondents who received 
socialization of Family Planning Program, but some did not actively participate in the activities. The majority of respondents who plan to continuously use long-term contraceptives will invite their relatives/neighbors to use the same contraceptive method too. Community participation points the success of Family Planning Program. The program may be failed if community are reluctant to get involved in such program (Agustini, Wati, and Ramani, 2015).

Table 4. Participation of Respondents.

\begin{tabular}{lrr}
\hline Participation & $\mathbf{n}$ & $\%$ \\
\hline Less & 5 & 20.8 \\
Moderate & 10 & 41.2 \\
Good & 9 & 37.5 \\
\hline Total & 24 & 100 \\
\hline
\end{tabular}

At the end of January 2018, there was a slight increase in the family planning participation in Dukuhsia Village even though it was still far beyond the target. Since 2016 the increase in long-term contraception was as many as 20 users (14 implant users and 6 tubectomy users). However, it has not significantly risen the proportion of long-term contraceptive use in Family Planning Village Program.

\section{CONCLUSION}

In summary, most of the input factors are not in accordance with the technical guidelines for Family Planning Village Program because of insufficient number because of few Family Planning Outreach Workers, no funding for the activities, and incomplete infrastructure, whereas the implementation method is in accordance with the program guidelines and objectives. Most aspects of the process factor obey the instructions even though there are still many obstacles from the internal and external management. In terms of output, the respondents mostly have enough knowledge of long-term contraception and receive family planning services in primary healthcare centers, which they can reach by motorcycles. All respondents are not required to make payments for family planning services. The participation of respondents in the Family Planning Program is moderate, indicating that there is an increasing number of longterm contraceptive users. In total, there are only 20 long-term contraceptive users, but it is not able to significantly increase the ideal proportion of long-term contraceptives in Dukuhsia.

Therefore, it is necessary to improve input and management aspects of the Family Planning Village through intensive coordination in allocating funds with the village government. The process aspects of the Family Planning Village need to increase through the Contraceptive Technology Update (CTU) training for midwives and conduct a training for cadres to improve their communicative skills for better campaign of LTCM use.

\section{CONFLICT OF INTEREST}

The authors stated that there is no conflict of interest for this article.

\section{REFERENCES}

Afniyanti (2016) 'Kinerja Petugas Lapangan Keluarga Berencana (PLKB) di Desa Pakawa Kecamatan Pasangkayu Kabupaten Mamuju Utara', IKatalogis, 4(4), pp. 178-187. Agustini, R., Wati, D. M. and Ramani, A. (2015) 'Kesesuaian Penggunaan Alat Kontrasepsi Berdasarkan Permintaan KB pada Pasangan Usia Subur ( PUS ) di Kecamatan Puger Kabupaten Jember', e-Jurnal Pustaka Kesehatan, 3(1), pp. 155162.

Devi, S., Fatchiya, A. and Susanto, D. (2016) 'Kapasitas Kader dalam Penyuluhan Keluarga Berencana di Kota Palembang, Provinsi Sumatera 
Selatan', Jurnal Penyuluhan, 12(2), p. $144 . \quad$ doi: 10.25015/penyuluhan.v12i2.11223.

Dewi, P. S. (2016) . Hubungan Usia Dan Paritas Dengan Penggunaan Metode Kontrasepsi Jangka Panjang Pada Akseptor Baru Di Puskesmas Lendah 1 Kulon Progo, Universitas 'Aisyiyah Yogyakarta. Yogyakarta.

East Java Provincial Health Office (2015) Profil Kesehatan Jawa Timur Tahun 2015. Surabaya: Dinas Kesehatan Provinsi Jawa Timur.

East Java Provincial Health Office (2017) Profil Kesehatan Jawa Timur Tahun 2017. Surabaya: Dinas Kesehatan Provinsi Jawa Timur.

East Java Provincial National Board of Population and Family Planning (2017) Evaluasi Program KKBPK September 2017. Jakarta: BKKBN.

Fienalia, R. A. (2012) Faktor-Faktor Yang Berhubungan Dengan Penggunaan Metode Kontrasepsi Jangka Panjang (MKJP) Di Wilayah Kerja Puskesmas Pancoran Mas Kota Depok Tahun 2011. Universitas Indonesia. Available at: http://lib.ui.ac.id/detail?id=20294580 \&lokasi=lokal\#horizontalTab2.

Getahun, D. S. et al. (2018) 'Utilization and determinants of long term and permanent contraceptive methods among married reproductive age women at Janamora district, northwest Ethiopia', BMC Research Notes. BioMed Central, 11(1), pp. 16. doi: 10.1186/s13104-018-3942-0.

Indonesian Ministry of Health (2013) Situasi Keluarga Berencana di Indonesia. Jakarta: Kementerian Kesehatan Republik Indonesia.

Jember District Health Office (2014) Profil Kesehatan Kabupaten Jember tahun 2014. Jember: Dinas Kesehatan Kabupaten Jember.

Jember District Health Office (2016) Profil Kesehatan Kabupaten Jember tahun 2016. Jember: Dinas Kesehatan Kabupaten Jember.

Kartika, Budihastuti, U. R. and Pamungkasari, E. P. (2017) 'Determinants of Long-Term Contraceptive Method Use in Madiun, East Java: Application of
Social Cognitive Theory', Journal of Health Promotion and Behavior, 2(4), pp. 313-322. doi: 10.26911/thejhpb.2016.02.04.03.

Kurnia, R. (2013) 'Studi Tentang Implementasi Program Keluarga Brencana di Kecamatan Sepaku Kabupaten Penajam Paser', eJournal Administrasi Negara, 1(4), pp. 1673-1684.

Landa, E. (2018) 'Influence of Training on Employees Performance in Public institution in Tanzania', International Journal of Human Resource Studies, 8(2), p. $324 . \quad$ doi: 10.5296/ijhrs.v8i2.13136.

Muhatiah, R. (2012) 'Partisipasi Pria Dalam Program Keluarga Berencana (Kb)', Marwah: Jurnal Perempuan, Agama dan Jender, 11(1), p. 1. doi: 10.24014/marwah.v11i1.502.

Murniati, S., Astuti, D. S. and Juliantari, I. (2016) 'Hubungan Sosial Budaya Dan Status Ekonomi Terhadap Tingginya Pemakaian Alat Kontrasepsi Suntik Di Desa Karang Bayan Kecamatan Lingsar Wilayah Kerja Puskesmas Sigerongan', Prima, 2(2), pp. 20-30.

Muslikh, I. and Nugraha, C. A. (2014) 'Analisis faktor-faktor yang Mempengaruhi Kinerja Pembantu Pembina Keluarga Berencana Desa (PPKBD) dalam Pencapaian Keberhasilan Keluarga Berencana (KB) Pria di Kabupaten Pemalang.', Media Ekonomi Dan Manajemen, 29(2), pp. 181-194.

National Board of Population and Family Planning (2015) Petunju Teknis Kampung KB. Jakarta: BKKBN.

National Board of Population and Family Planning (2016) Pedoman Pelaksanaan Integrasi Kampung KB Bersama Mitra Kerja Tahun Anggaran 2016. Jakarta: BKKBN.

Oyugi, B. et al. (2017) 'Accessibility of long-term family planning methods: a comparison study between Output Based Approach (OBA) clients verses non-OBA clients in the voucher supported facilities in Kenya', BMC Health Services Research. BMC Health Services Research, 17(1), pp. 1-11. doi: 
10.1186/s12913-017-2164-9.

Rahayu, S. (2016) 'Kesesuaian Pelayanan Kontrasepsi AKDR oleh Bidan Terhadap Pelaksanaan SOP di Puskesmas Kota Semarang', Gaster, XIV(2), pp. 26-37.

Rosmadewi (2015) 'Hubungan Pengetahuan dan Tingkat Ekonomi dengan Penggunaan Alat Kontrasepsi', Jurnal Kesehatan Metro Sai Wawai, VIII No.1(Edisi Juni 2015), pp. 19-24.

Sarini Vivi Yanti Kartini Hasballah, M. (2016) 'Studi Komparatif Kinerja Kader Posyandu', Jurnal IImu Keperawatan, 4(2), pp. 1-11.

Sutopo (2014) Metode Penelitian Kuantitatif, Kualitatif, dan Kombinasi
(Mix Methods). Bandung: Alfabeta.

Tesfaye Haile, T. and Anjullo, B. B. (2018) 'The Prevalence and Determinants of Preference of Long Term Contraceptive Methods among Married Women in Arba Minch Town, Ethiopia', International Journal of Biomedical Materials Research, 6(2), pp. 26-34. doi: 10.11648/j.ijbmr.20180602.11.

Tibaijuka, L. et al. (2017) 'Factors influencing use of long-acting versus short-acting contraceptive methods among reproductive-age women in a resource-limited setting', $B M C$ Women's Health. BMC Women's Health, 17(1), pp. 1-13. doi: 10.1186/s12905-017-0382-2. 